\title{
Researching into a Course of Information Technologies and Software in The Context of Digital Citizenship through Student Opinions
}

\author{
Agâh Tuğrul Korucu ${ }^{1}$ \\ Department of Computer Education and Instructional Technology, Ahmet Kelesoglu Faculty \\ of Education, Necmettin Erbakan University, Konya / TURKEY
}

Havva Nur TOTAN

Department of Computer Education and Instructional Technology, Ahmet Kelesoglu Faculty of Education, Necmettin Erbakan University, Konya / TURKEY

\begin{tabular}{|c|c|}
\hline Artic & \multirow{7}{*}{$\begin{array}{l}\text { Information technologies literate is an individual who produces } \\
\text { information, can use it functionally in life, can solve problems, think } \\
\text { critically, has entrepreneurial, stable, communication skills, empathizes, } \\
\text { contributes to society and culture etc. The purpose of this research is to } \\
\text { examine the effectiveness of "Information Technologies and Software } \\
\text { Course (ITS)" in gaining knowledge, skills and values of digital } \\
\text { citizenship with student views. Mixed research method has been adopted } \\
\text { in the research. The sample of the study consisted of } 150 \text { students } \\
\text { attending the 5th and 6th grade students in a public secondary school in } \\
\text { Aksaray province in the } 2018-2019 \text { academic year. } 50 \text { students ( } 33.3 \%) \\
\text { were in the fifth grade and } 100(66.7 \%) \text { were in the sixth grade and } 86 \\
\text { (57.3\%) were female and } 64(42.7 \%) \text { were male. "Digital Citizenship } \\
\text { Scale (DCS) in ITS Scale" developed by Elci and Sarl (2016) was used as } \\
\text { a measurement tool. The obtained data were interpreted by using } \\
\text { independent sample t-test and one-way analysis of variance in the } \\
\text { analysis programs. As a result of the research; in the ITS course of the } \\
\text { students, it has been observed that students have differentiated according } \\
\text { to the variables of gaining knowledge, skills and values of digital } \\
\text { citizenship, class, gender, socioeconomic status and having Internet } \\
\text { access. However, it was found that there were no differences in terms of } \\
\text { computer ownership status, mothers' education level and fathers' } \\
\text { education level. }\end{array}$} \\
\hline & \\
\hline & \\
\hline & \\
\hline & \\
\hline & \\
\hline & \\
\hline
\end{tabular}

\section{Introduction}

In our age, technologies have been developed in every field of our lives, as expressed in "the information society" (Erdogan et al., 2010), according to the expectations of individuals in societies develop depending on developing technologies (Ercetin \& Durak, 2017). In order to keep up with these changing expectations, it has become obligatory to educate individuals who have the ability to use information technologies for specific purposes

\footnotetext{
${ }^{1}$ Correspondence: akorucu@erbakan.edu.tr
} 
(Dirisaglık \& Kabakc1, 2009; Usta \& Korkmaz, 2010; Tanrıgen \& Ozel, 2011; Ercetin \& Durak, 2017). It can be said that these necessitates individuals to be literate in IT technologies (Dursun \& Cuhadar, 2009). Information technologies literate is an individual who produces information, who can use this information functionally in life, also who can solve problems, think critically, who owns entrepreneurial, stable, communication skills, who empathizes, contributes to society, culture and so on. (Board of Education, 2018).

Information and communication technologies, with individuals who possess the freedom to acquire, produce and disseminate information, citizenship rights and responsibilities in the virtual world, have become more common (Elci \& Sar1, 2016). Also as Cubukcu and Bayzan (2013) stated in their research the day-to-day rapid increase of information and communication technologies and the efficient use of smart technology devices by children and teenagers in Turkey alongside the entire world have led to the emergence of digital citizenship notion. First of all, to define the concept of citizenship; it can be said that it is the nationality linking a person to the state (Kepeneksi, 2013; Gormez, 2016). According to Kizilay (2015), the concept of citizen means being active in the issues related to the state and society, rather than being an individual connected to the state through developments. As a traditional term, citizenship emphasizes the relationship between the individual and the state; whereas digital citizenship emphasizes the citizen equipped with active and democratic values who use mass media to obtain information (Simsek \& Simsek, 2013). Mossberger, Tolbert and $\mathrm{McNeal}$ (2008) describe digital citizenship as the ability to participate in society online. A digital citizen is a citizen who can criticize when using information and communication resources, knows the ethical consequences of their online behavior, does not misuse technology, communicates and cooperates in the digital world, demonstrates correct and moral behavior and encourages people to do so (Colak, 2017). Thus digital citizenship is more than just knowing and teaching how a tool is used, but a way of transferring children and users to what they should do when they are online in a technology-centered society (digitalcitizenship.net, 2018). Ribble et al. (2011) mentioned the 9 sub-dimensions of digital citizenship in his studies. These dimensions are expressed as follows:

- Digital access refers to full electronic involvement in society (Alberta, 2012). Cubukcu and Bayzan (2013) refer to digital access as having access to digital technology at a high speed and in everywhere possible.

- Digital commerce covers the protection of confidentiality in online banking and shopping systems, being aware and capable of receiving goods and services in online platforms and being aware of shopping and trading in secure internet pages (Cubukcu \& Bayzan, 2013).

- Digital Communication is electronic information exchange (Alberta, 2012). It is the usage of communication resources at the right time and in the right way and exchanging information on digital platforms (Cubukcu \& Bayzan, 2013).

- Digital Literacy, according to Gurcan (2013), is the ability to understand and use a wide range of multi-formatted information technologies through computers. Technology facilititates the process of learning and teaching (Alberta, 2012).

- Digital ethics is defined as having information about when and how to use digital instruments and respecting the rights of others when using them (Cubukcu \& Bayzan, 2013).

- Digital Rights and Responsibilities are expressed as freedoms given to those in the digital world (Alberta, 2012). 
- Digital law is to be aware of the rules, policies and laws that apply in the digital environment, also to observe and warn those who are not (Cubukcu \& Bayzan, 2013). It is defined as the responsibility of transactions made with electronic goods (Alberta, 2012).

- Digital security is personal information security, as well as hardware, software and network security when using digital tools (Cubukcu \& Bayzan, 2013).

- Digital health is the awareness of the physical and psychological health problems caused by the digital world.

When the literature is examined, it is observed that various studies have been conducted on digital citizenship (Şimşek \& Şimşek, 2013; Ocak, 2013; Karahisar, 2013; Cubukcu \& Bayzan, 2013; Cepni, Oguz \& Kilcan, 2014; Karaduman \& Ozturk, 2014; Kaya \& Kaya, 2014; Görmez, 2016; Vural \& Kurt, 2017). Nowadays, the perception of being a good citizen, and the path towards becoming a good digital citizen, now requires the extension of citizenship education to include digital citizenship (Er, Ünal \& Özmen, 2013). It is thought that the most important contribution to this subject is the information technologies course which is compulsory in secondary schools. In the literature, Elçi and Sarı (2016) has research on the analysis of information technologies and software in the context of digital citizenship. As stated by Elçi and Sarı (2016) in their research, it is important to increase the number of research in order for schools, which are the primary responsible institutions in raising citizens, need to reorganize their responsibilities within the scope of digital citizenship and to create awareness in that sense. In addition, it was thought that it would be beneficial to reconduct relevant studies due to the updating of the information technology and software course curriculum on July 18, 2017 (Board of Education, 2017).

The information technology and software course, which was called as computer lesson before 2007, was taken to a compulsory course status in the 5th and 6th grades of primary education institutions in the secondary school section of the primary education institutions. This was realized upon the proposal letter of the General Directorate of Basic Education dated 08.05.2013 and numbered 886487 (Board of Education, 2013). In the 7 th and 8 th grades, it is seen that this course is within the scope of elective courses, taught 2 hours per week. Among the specific objectives of the information technology and software course curriculum are ensuring students evolve into individuals who understand the technological concepts, systems and processes well as digital citizens (Board of Education, 2018). Under the title of Ethics and Security Unit in the curriculum; concepts such as information confidentiality and security, ethical values and digital citizenship are mentioned.

The achievements of the digital citizenship subheading for Grades 5 and 6 are as follows; "Understanding the purposes of using digital citizenship applications.", "Examining applications such as e-government, e-appointment, e-banking, e-school.", "realizing that digital identities may not reflect the truth.", "realizing that digital shares are permanent and leave traces behind.", "Realizing the effects of digital sharing on itself and others.", "Distinguishing between digital games and content that are suitable for cognitive and moral development." (Board of Education, 2018).

To that end the aim of this research is to determine the opinions of secondary school students on information technologies and software course. Therefore, within the scope of this research, the digital citizenship sub-topic in the curriculum of information technologies and software courses which is compulsory in the 5th and 6th grades of secondary school is evaluated looking at and checking the views of the students. In order to achieve this goal, answers to the 
following questions were sought;

(1) Is there a significant difference between the views of students about the level of gaining knowledge and skills of digital citizenship in terms of their;
a) grade level
b) gender
c) socioeconomic status
d) owning a computer at home or not
e) having internet access at home or not
f) parental education level

(2) What are the students' views on increasing the effectiveness of the ITS course?

\section{Method}

\section{Research Model}

In this study, mixed research is adopted as the research method. Survey study was used in the quantitative part. A scale was used to collect data. According to Karasar (2006), general scanning models are screening arrangements made on the entire population or on a group of sample taken from the population in order to reach a general judgement of the population consisting of numerous elements. In the qualitative part of the study, data were collected by semi-structured interviews. The open-ended question added to the end of the scale was used to collect the data. In the analysis of qualitative data, content analysis was used.

\section{Population and Sample}

The population of the study consists of the 5th and 6th grade students who continue their education at the middle school level of the primary schools in Eskil district of Aksaray in 2018-2019 academic year. The sample of the study is composed of the 5th and 6th grade students in two middle schools selected by simple random sampling method from the schools in the population. 150 students participated in the study. The personal information and demographic data of the students are presented in Table 1.

Table 1. Demographic Data of Students

\begin{tabular}{llll}
\hline & & $\mathbf{F}$ & $\mathbf{\%}$ \\
\hline Grade & 5. Grade & 50 & 33.3 \\
Gender & 6. Grade & 100 & 66.7 \\
& Female & 86 & 57.3 \\
Economic income of the family & Male & 64 & 42.7 \\
& Below 1000 TL 1000- & 27 & 18.0 \\
& 2000 TL & 50 & 33.3 \\
Computer existence at home & $2000-3500$ TL & 51 & 34.0 \\
& 3500 TL and above & 22 & 14.7 \\
Internet access existence at home & Yes & 74 & 49.3 \\
& No & 76 & 50.7 \\
& Yes & 123 & 82.0 \\
\hline
\end{tabular}

$50(33.3 \%)$ of the participants were in the 5 th grade and $100(66.7 \%)$ were in the 6 th grade. $86(57.3 \%)$ were female and $64(42.7 \%)$ were male. $27(18 \%)$ of the participants expressed the economic income of the family as below $1000 \mathrm{TL}, 50(33.3 \%)$ between 1000-2000 TL, 51 (34\%) between 2000-3500 TL, $22(14,7 \%)$ of the participants stated that they receive $3500 \mathrm{TL}$ 
and above. While $74(49.3 \%)$ of the participants had a computer at home, $76(50.7 \%)$ did not. At the same time, $123(82 \%)$ of the participants had internet access, while $27(18 \%)$ of them did not have internet access at home.

\section{Data collection tool}

As the data collection tool, Digital Citizenship Scale developed by Elçi and Sarı (2016) was used in Information Technologies and Software Course (ITS-DCS). ITS-DCS consists of 5-point Likert-type grading (5- Multi-contribution, 4- Contribution, 3- A little contribution, 2-No Contribution, 1- No contribution at all) and it consists of 48 items which aim to measure the extent to which digital citizenship characteristics, which are the subdimension of science curriculum, are gained. In the first part of the scale, questions about getting personal information are included. At the end of the scale, an open-ended question was used to determine the views of students about increasing the effectiveness of the ITS course in gaining knowledge, skills and values of digital citizenship. ITS-DCS consists of four sub-scales. These are; "Digital Ethics-Law", "Related Rights and Responsibilities", "Digital literacy", "Digital security", "Digital communication" subscales. According to the validity and reliability of the studies of Elçi and Sarı (2016), 4 subscales' have total variance \%54.10. The Cronbach Alpha internal consistency coefficient for the whole scale is .97.

\section{Data Analysis}

The data obtained using the data collection tool were processed according to various categories after being transferred to the computer environment. "SPSS" statistical package programs were used for statistical analysis of quantitative data. In addition to the descriptive statistical analyses, parametric tests were used in the tests performed with the collected data because of the normal distribution of the data both $n=150$ and the number of participants. In these tests; Independent sample t-test and one-way analysis of variance (ANOVA) techniques were used. Post Hoc Multiple Comparison Test was used to test the difference between the groups for which $\mathrm{F}$ value was significant after ANOVA. $\mathrm{p}=.05$ level of significance was detected in the evaluation of the findings.

\section{Findings}

The findings related to the level of gaining knowledge and skills of digital citizenship in Information Technologies and Software course are examined in this section of this research.

\section{Findings of the Contribution of Information Technology and Software Course in the Development of Digital Citizenship Knowledge, Skills and Values by Class Level}

According to the results of the independent sample t-test seen in Table 2, there is a significant difference between the ITS-DCS scores of the students and the class variable $(\mathrm{t}(148)=-2.320, \mathrm{p}<.05)$.

When the total scores of the participants were evaluated; the average score of 6th grade students is higher than the 5 th grade students and this difference is statistically significant (Grade 5 average $\bar{x}=186.16$; Grade 6 average $\bar{x}=199.56$ ). 
Table 2. Independent Sample t-test Results of Class Variables

\begin{tabular}{lllllll}
\hline & $\mathbf{N}$ & $\overline{\mathbf{x}}$ & $\mathbf{s s}$ & $\mathbf{s d}$ & $\mathbf{t}$ & $\mathbf{p}$ \\
\hline 5.Grade & 50 & 186.16 & 31.91 & 148 & -2.320 & .022 \\
6.Grade & 100 & 199.56 & 34.02 & & & \\
\hline
\end{tabular}

$* \mathrm{p}<0.05$

Findings of the Contribution of Information Technology and Software Course in Gaining Digital Citizenship Knowledge, Skills and Values by Gender

According to the independent sample t-test results observed in Table 3, it is seen that there is a meaningful difference between the ITS-DCS scores and the gender variable $\left(\mathrm{t}_{(148)}=-\right.$ $2.638, \mathrm{p}<.05)$.

When the total ITS-DCS scores of the participants were examined; the average score of female students is higher than that of male students and this difference is statistically significant. (The average of female students is $\bar{x}=201.25$; the average of male students is $\bar{x}=$ 186.81).

Table 3. Independent Sample t-test Results of Gender Variable

\begin{tabular}{lllllll}
\hline & $\mathbf{N}$ & $\overline{\mathbf{x}}$ & $\mathbf{s s}$ & $\mathbf{s d}$ & $\mathbf{t}$ & $\mathbf{p}$ \\
\hline Female & 86 & 201.25 & 30.47 & 148 & 2.638 & .009 \\
Male & 64 & 186.81 & 36.49 & & & \\
\hline$* \mathrm{p}<0.05$ & & & & & &
\end{tabular}

$* \mathrm{p}<0.05$

Findings of the Contribution of Information Technologies and Software Course to Digital Citizenship Knowledge, Skills and Values According to Family's Income Level

Table 4 and Table 5 show the findings that the scores of the participants from ITSDCS vary according to their family's income level.

Table 4. Results of Participants' ITS-DCS Points By Monthly İncome Level

\begin{tabular}{llll}
\hline & $\mathbf{N}$ & $\overline{\mathbf{x}}$ & ss \\
\hline Below 1000 TL & 27 & 178.62 & 40.12 \\
Between 1000-2000 TL & 50 & 196.80 & 32.46 \\
Between 2000-3500 TL & 51 & 199.00 & 31.61 \\
3500 TL and above & 22 & 202.36 & 28.98 \\
& & & \\
\hline Total & 150 & 195.09 & 33.82 \\
\hline
\end{tabular}

Table 5. ANOVA Results According to The Family Economic Levels

\begin{tabular}{llllll}
$\begin{array}{l}\text { Total of } \\
\text { Squares }\end{array}$ & $\begin{array}{l}\text { Degree of } \\
\text { Permissive } \\
\text { ness }\end{array}$ & $\begin{array}{l}\text { Squares } \\
\text { Average }\end{array}$ & $F$ & $p$ & $\begin{array}{l}\text { Meaningful } \\
\text { Difference }\end{array}$ \\
\hline
\end{tabular}

\begin{tabular}{|c|c|c|c|c|c|c|c|}
\hline & & & & & & & \\
\hline Below 1000 TL & & & & & & & \\
\hline & $\begin{array}{l}\text { Between } \\
\text { Groups }\end{array}$ & 9405.30 & 3 & 3135.10 & & & \\
\hline Between 1000- & & & & & & & $1-2$ \\
\hline $2000 \mathrm{TL}$ & & & & & 2.841 & .040 & $1-3$ \\
\hline Between 2000- & & & & & & & \\
\hline $3500 \mathrm{TL}$ & In-group & 161093.3 & 146 & 1103.37 & & & \\
\hline $\begin{array}{lll}3500 & \text { TL } & \text { and } \\
\text { above } & & \end{array}$ & & & & & & & \\
\hline
\end{tabular}


$(1=1000 \mathrm{TL}$ below, $2=$ between $1000-2000 \mathrm{TL}, 3=$ between $2000-3500 \mathrm{TL}, 4=3500 \mathrm{TL}$ and above)

As seen in Table 5, according to the findings obtained by using single-factor variance analysis (ANOVA) for independent samples, it is seen that there is a significant difference between the scores of the participants from ITS-DCS according to the monthly income level of the family $(\mathrm{F}(3-146)=2.841, \mathrm{p}<.05)$. In other words, participants' gaining knowledge, skills and values of digital citizenship in the ITS course vary according to the monthly income level of their families. Post-hoc test statistics were applied to determine which group caused this difference. According to LSD test; it was concluded that there were significant differences between 1, 2, 3 and 4.

\section{Findings of the Contribution of Information Technologies and Software Course to Gaining Digital Citizenship Knowledge, Skills and Values According to Computer Ownership Status}

According to the independent sample t-test results seen in Table 6, there was no significant difference between the ITS-DCS scores and the computer ownership variable $(\mathrm{t}(148)=-206$, $\mathrm{p}>.05$ ). In other words, in the course of ITS students gain knowledge, skills and values of digital citizenship that do not change according to whether they have a computer at home or not.

Table 6. T-test Results of Computer Ownership Variable

\begin{tabular}{lllllll}
\hline & N & $\overline{\mathbf{x}}$ & ss & sd & t & p \\
\hline Yes & 74 & 194.51 & 35.08 & 148 & -.206 & .837 \\
No & 76 & 195.65 & 32.77 & & & \\
\hline$* \mathrm{p}<0.05$ & & & & & &
\end{tabular}

Findings of the Contribution of Information Technologies and Software Course to Gaining Digital Citizenship Knowledge, Skills and Values According to Internet Access

According to the independent sample t-test results seen in Table 7, there is a significant difference between the ITS-DCS scores and internet access variable $(t(33.38)=3.333, \mathrm{p}<.05)$. When ITS-DCS scores of the participants were examined; it is seen that the average score of the students with internet access at home is higher than the students without internet access and this difference is statistically significant (the average of those with internet access is $\bar{x}=$ 199.90; the average of those without Internet access is $\overline{\mathrm{x}}=173.18$ ).

Table 7. T-test Results of Internet Access Variable

\begin{tabular}{lllllll}
\hline & $\mathbf{N}$ & $\overline{\mathbf{x}}$ & $\mathbf{s s}$ & $\mathbf{s d}$ & $\mathbf{t}$ & $\mathbf{p}$ \\
\hline Yes & 123 & 199.90 & 30.69 & 33.38 & 3.333 & .002 \\
No & 27 & 173.18 & 39.08 & & & \\
\hline
\end{tabular}

$* \mathrm{p}<0.05$

Findings of the Contribution of Information Technology and Software Course to Gaining Digital Citizenship Knowledge, Skills and Values According to Mothers' Education Level

Table 8 and Table 9 show that the scores of the participants' ITS-DCS scores vary according to the level of mothers' education. 
Table 8. Results of Participants' ITS-DCS Scores According to Mothers' Education Level

\begin{tabular}{llll}
\hline & $\mathbf{N}$ & $\overline{\mathbf{x}}$ & $\mathbf{s s}$ \\
\hline You can't read and write & 3 & 173.33 & 22.05 \\
You can read and write & 2 & 173.00 & 66.46 \\
Primary school & 75 & 191.38 & 35.12 \\
Middle School & 51 & 202.19 & 28.11 \\
High school & 15 & 195.60 & 40.57 \\
University and Above & 4 & 199.50 & 41.58 \\
\hline Total & 150 & 195.09 & 33.82 \\
\hline
\end{tabular}

Table 9. ANOVA Results by Mothers' Education Level

\begin{tabular}{|c|c|c|c|c|c|c|c|}
\hline & & $\begin{array}{l}\text { Total of } \\
\text { Squares }\end{array}$ & $\begin{array}{l}\text { Degree of } \\
\text { Permissive } \\
\text { ness }\end{array}$ & $\begin{array}{l}\text { Squares } \\
\text { Average }\end{array}$ & $\mathbf{F}$ & $\mathbf{p}$ & $\begin{array}{l}\text { Meaningfu } \\
\text { I } \\
\text { Difference }\end{array}$ \\
\hline $\begin{array}{l}\text { You can't read } \\
\text { and write }\end{array}$ & \multirow{3}{*}{$\begin{array}{l}\text { Between } \\
\text { Groups }\end{array}$} & \multirow{3}{*}{6081.601} & \multirow{3}{*}{5} & \multirow{3}{*}{1216.320} & \multirow{7}{*}{1.065} & \multirow{7}{*}{.382} & \multirow{7}{*}{--} \\
\hline $\begin{array}{l}\text { You can read } \\
\text { and write }\end{array}$ & & & & & & & \\
\hline Primary school & & & & & & & \\
\hline Middle School & \multirow{4}{*}{$\begin{array}{l}\text { In- } \\
\text { Group }\end{array}$} & \multirow{4}{*}{164417.09} & \multirow{4}{*}{144} & \multirow{4}{*}{1141.785} & & & \\
\hline High school & & & & & & & \\
\hline & & & & & & & \\
\hline $\begin{array}{l}\text { University and } \\
\text { Above }\end{array}$ & & & & & & & \\
\hline
\end{tabular}

As seen in Table 9, according to the findings obtained by using single-factor variance analysis (ANOVA) for independent samples, there was no significant difference between the scores of the participants from their ITS-DCS scores according to their mothers' education level ( $\mathrm{F}(5-$ $144)=1.065, \mathrm{p}>.05)$. Namely the participants do not change their knowledge, skills and values in ITS course according to their mothers' education level.

Findings of the Contribution of Information Technology and Software Course to Gaining Digital Citizenship Knowledge, Skills and Values According to Fathers' Education Level

Table 10 and Table 11 show that participants' scores of ITS-DCS vary according to the level of their fathers' education.

Table 10. Results of the ITS-DCS Points of The Participants According to The Level of Fathers' Education

\begin{tabular}{llll}
\hline & N & $\overline{\mathbf{x}}$ & ss \\
\hline Primary school & 52 & 186.28 & 33.08 \\
Middle School & 42 & 199.45 & 32.03 \\
High school & 42 & 200.52 & 33.39 \\
University and Above & 14 & 198.42 & 39.86 \\
\hline Total & 150 & 195.09 & 33.82 \\
\hline
\end{tabular}


Table 11. ANOVA Results by Fathers' Education Level

\begin{tabular}{|c|c|c|c|c|c|c|c|}
\hline & & $\begin{array}{l}\text { Total of } \\
\text { Squares }\end{array}$ & $\begin{array}{l}\text { Degree of } \\
\text { Permissiv } \\
\text { eness }\end{array}$ & $\begin{array}{l}\text { Squares } \\
\text { Average }\end{array}$ & $\mathbf{F}$ & $\mathbf{p}$ & $\begin{array}{l}\text { Meaningful } \\
\text { Difference }\end{array}$ \\
\hline $\begin{array}{l}\text { Primary } \\
\text { school }\end{array}$ & \multirow[t]{2}{*}{$\begin{array}{l}\text { Between } \\
\text { Groups }\end{array}$} & \multirow[t]{2}{*}{6223.71} & \multirow[t]{2}{*}{3} & \multirow[t]{2}{*}{2074.57} & \multirow{4}{*}{1.844} & \multirow{4}{*}{.142} & \multirow{4}{*}{--} \\
\hline $\begin{array}{l}\text { Middle } \\
\text { School }\end{array}$ & & & & & & & \\
\hline $\begin{array}{l}\text { High } \\
\text { school }\end{array}$ & \multirow[t]{2}{*}{$\begin{array}{l}\text { In- } \\
\text { Group }\end{array}$} & \multirow[t]{2}{*}{164274.98} & \multirow[t]{2}{*}{146} & \multirow[t]{2}{*}{1125.17} & & & \\
\hline $\begin{array}{l}\text { University } \\
\text { and Above }\end{array}$ & & & & & & & \\
\hline
\end{tabular}

As seen in Table 11, according to the findings obtained by using single factor variance analysis (ANOVA) for independent samples, there was no significant difference between the scores of the participants from their ITS-DCS scores according to their fathers' education level $(\mathrm{F}(3-146)=1.844, \mathrm{p}>.05)$. In other words, the participants do not change their knowledge, skills and values in ITS course according to the level of fathers' education.

\section{Findings Regarding Students' Views on Increasing the Effectiveness of ITS Course}

The data on the answers of the students to the "What do you think can be done in order to increase the effectiveness of the ITS course?" open-ended question in the ITS-DCS are shown in Table 12. As seen in Table 12, students' views on increasing the effectiveness of information technologies and software course are generally grouped under course hours, learning-teaching processes and hardware-infrastructure themes. The theme of learningteaching processes is coded as method-technique and material.

Table 12. Data on Students' Views on Increasing the Effectiveness Of ITS Course

\begin{tabular}{llll}
\hline Theme & Codes & f & \% \\
\hline Course Hours & & 10 & 10.0 \\
Teaching Processes & Method Technical & 23 & 23.0 \\
Hardware-Infrastructure & Materiel & 37 & 37.0 \\
Other & & 28 & 28.0 \\
\hline Total & & 2 & 2.0 \\
\hline
\end{tabular}

The theme of the lesson was $n=10$, which was based on the student views to increase the effectiveness of the ITS course. Some of the student opinions included in the course hours theme are as follows:

"IT courses should continue in 7th and 8th grades. So we do not forget what we have learned and apply it in daily life." (S19)

"Course hours must be increased. In the 7th and 8th grades, we can forget about the information we learned because there is no IT course." (S73)

From the codes determined for the theme of the teaching-learning process, the technique was determined as $\mathrm{n}=23$ and the material was $\mathrm{n}=37$. Some of the student opinions included in the theme of the teaching-learning process are as follows:

"The course can be performed with various activities, games can be played about the course, videos can be watched, we can learn new information on the computer." (S2) 
"Some issues are difficult. If these subjects are turned into a game and made fun, I can better understand these, and they become permanent." (S15)

"It would be more efficient if we practiced more in computer science course than we did with computers." (S100)

"It would have been more effective if we had an ICT book. We could have followed the topics from there and we would not have wasted time taking notes. We would have had more time to practice from the computer." (S33)

The hardware-substructure theme was determined as $n=28$ from the views of the students about increasing the effectiveness of the ITS course. Some of the student views included in the hardware-infrastructure theme are as follows:

"I think the computer class is small. If the class is large and the computers are renewed, we will learn more efficiently." (S25)

"The computers in our classes are not working properly because they are old. Computers in our IT class can be renewed." (S98)

Other students' views on improving the effectiveness of the ITS course are as follows:

“Courses related to information technologies can be opened." (S11)

"Less efficient if we open the computer in lessons." (S67)

\section{Discussion and Conclusion}

150 students participated in this research for the contribution of Information Technology and Software course in gaining knowledge, skills and values of digital citizenship. Findings obtained from the research are as follows:

It is determined that there is a significant difference according to class variable in acquiring digital citizenship knowledge, skills and values of ITS course. ITS-DCS total score averages of the 6th grade students $(\bar{x}=199.56)$ were higher than those of the 5th grade students $(\overline{\mathrm{x}}=186.16)$ and this difference was statistically significant $(\mathrm{t}(148)=-2.320, \mathrm{p}<.05)$. This finding is consistent with Elçi \& Sarı's (2016) research in the literature. Elçi \& Sarı (2016) explained this difference in favor of Grade 6 students with the fact that the students studying in the sixth grade had received more than two semesters of ITS lessons from the students studying in the $5^{\text {th }}$ grade.

It has also been determined that there is a significant difference according to gender variable in acquiring digital citizenship knowledge, skills and values of ITS course. It was observed that female students' $(\bar{x}=201.25)$ ITS-DCS total score averages were higher than the male students $(\overline{\mathrm{x}}=186.81)$ and this difference was statistically significant $(\mathrm{t}(148)=-2.638, \mathrm{p}<.05)$. When the literature is reviewed, it can be seen that this finding is consistent with Som-Vural \& Kurt's (2017) research on "Digital Citizenship from University Students' Perspective". In the studies of Çepni, Oğuz \& Kılcan (2014) with primary school students, digital citizenship gains were found meaningful in favor of male students. Lastly, Elçi \& Sarı (2016) stated that there is no significant difference according to gender. 
In addition, it is determined that there is a significant difference according to family income level variable in acquiring digital citizenship knowledge, skills and values of ITS course $(\mathrm{F}(3-$ $146)=2.841, \mathrm{p}<.05)$. In other words, participants' acquisition of digital citizenship knowledge, skills and values in the course of ITS varies according to the family's income level. According to the LSD test conducted to determine which group caused this difference; it was concluded that there were significant differences between 1 with 2, 3 and 4. The results in similar studies are in parallel with this finding (Çepni, Oğuz \& Kılcan, 2014; Som-Vural \& Kurt, 2017). Som-Vural \& Kurt (2017), the right ratio between income level and digital citizenship gains stated that the increase in income level could be related to the increase in digital equipment and application opportunities.

On the other hand there is no significant difference between the ITS course and the ability to acquire digital citizenship knowledge, skills and values $(t(148)=-206, p>.05)$. In other words, the participants' knowledge, skills and values in the course of ITS do not change according to whether they have computers at home or not. When the literature is reviewed, the findings of this result are also witnessed (Elci \& Sar1 2016).

It has been determined that there is a significant difference in Internet access and gaining access to digital citizenship knowledge, skills and values in ITS course. It was observed that the average scores of the ITS-DCS of the students who had internet access at home $(\bar{x}=199.90)$ were higher than the students who did not have internet access $(\bar{x}=173.18)$ and this awareness was statistically significant $(\mathrm{t}(33.38)=3.333, \mathrm{p}<.05)$. This finding is consistent with similar studies (Çepni, Oğuz \& Kılcan, 2014; Elçi \& Sarı, 2016 ) in the literature.

Yet in the course of ITS, there was no significant difference between the level of maternal education and gaining knowledge, skills and values of digital citizenship $(\mathrm{F}(5-144)=1.065$, $\mathrm{p}>.05)$. In other words, the participants' knowledge, skills and values of digital citizenship in ITS course do not vary according to the level of mothers' education. In the literature, Çepni, Oğuz \& Kilcan (2014) have found opposite results in their studies.

Similarly, in the course of ITS, there was no significant difference between the level of fathers' education and the level of fathers' education $(\mathrm{F}(3-146)=1.844, \mathrm{p}>.05)$. In other words, participants' knowledge, skills and values in the course of ITS do not vary according to the level of fathers' education. This finding is consistent with the studies of Çepni, Oğuz \& Kilcan (2014) in the literature.

Data on students' answers to the open-ended question "What do you think can be done in order to increase the effectiveness of the ITS course?" were examined and it was seen that $60 \%$ of the answers were collected under the theme of teaching processes. $23 \%$ of the answers collected under this theme were determined by technique and $37 \%$ by material codes. The most common repetitive responses in teaching processes were that the computers should be used more effectively in the course and there should be a book for the course of ITS. Based on this result, it can be said that the lack of printed material in the hands of students negatively affected the efficiency of the course.

$28 \%$ of the students' answers to the open-ended question were gathered under hardwareinfrastructure contact. When the answers under this theme were examined, it was seen that the majority of the students stated that the computers in the IT class were old and inadequate. Based on this situation, it can be said that the lack of individual computers in the classroom decreases the efficiency of the course causing a loss of time. 
$10 \%$ of the students' answers to the open-ended question were collected under the theme of the lesson. The students stated that the weekly course hours were generally low. As a result of SWOT analysis regarding digital citizenship dimensions carried out by Çubukcu and Bayzan (2013) in their studies, it was revealed that teaching the digital citizens rights and responsibilities more accurately and effectively is a must prior to teaching them how to use technology in lesson content and that the state has great responsibilities in this regard. The acquisition of digital citizenship knowledge and skills may be possible by updating training programs in this direction. In line with this conclusion, it is considered important to develop the curriculum in order to educate the conscious digital citizen in the ITS course which has an important role in gaining the knowledge, skills and values of digital citizenship.

\section{Suggestions}

The results of this study were obtained by collecting quantitative and qualitative data on a scale applied to students. In future research, more detailed conclusions can be reached through interviews, observations and similar qualitative data collection methods pertaining to digital citizenship. This research was carried out in the province of Aksaray. By creating an environment in which broader participants could be provided, the sample could be expanded and the effectiveness of the ITS course in gaining knowledge, skills and values of digital citizenship in schools in different provinces can be measured. Thus, more general results can be achieved. The study group of this study consisted of middle school students. Similar studies can be made with high school students and university students to reach more comprehensive results. A similar study can be conducted with teachers and teacher candidates too who are to transfer the knowledge, skills and values of digital citizenship to students.

\section{Suggestions for the Effectiveness of the Course}

According to the findings obtained from ITS-DCS, situations such as; the lack of hardware in the Information Technology classes, the inability to install up-to-date software to old computers, the number of computers per student, the lack of a teacher guidebook and student book for the course cause the potential inefficiency of the course. For these reasons;

- A teacher's guide book can be prepared in accordance with the updated training program of the ITS course, and a course and a workbook can be prepared for the students.

- ITS course can be made compulsory in all class levels and weekly course hours can be increased. Hence continuity of the course can be assured.

- IT classes can be reconfigured according to evolving technology with powerful computers, with each student in the classroom having an individual computer. In this way, students will have the chance to practice what they have learned and can obtain more permanent information.

- For teachers, in-service trainings regarding the importance of gaining knowledge, skills and values of digital citizenship and so on can be arranged.

\section{References}

Alberta. (2012). Digital citizenship policy development guide, School Technology Branch Alberta Education, Canada.

Çepni, O., Oğuz, S. \& Kılcan, B. (2014). Primary School Students' Views Of

Digital Citizenship. Türkiye Sosyal Araştırmalar Dergisi, 18 (3), 251-266. 
Çolak, M. (2017). Information technology and software course, digital citizenship. https://bilgisayarbilim.com/dijital-vatandaslik/ Accessed via the internet on 02.02.2019

Çubukçu, A., \& Bayzan, Ş. (2013). Türkiye'de dijital vatandaşlık algısı ve bu algıyı internetin bilinçli, güvenli ve etkin kullanımı ile artırma yöntemleri [Digital citizenship perception in Turkey and the conscious perception of the internet, safe and effective methods of increasing use]. Middle Eastern \& African Journal of Educational Research, 5, 148-173.

Digitalcitizenship.net (2016). Digital Citizenship, Using Technology Appropriately. http://www.digitalcitizenship.net/home.html Accessed via the internet on 02.02.2019.

Dirisağlık, F. \& Kabakçı, I. (2008). Bilgisayar formatör öğretmenlerinin bilgi teknolojisi sınıflarının kullanımına ilişkin görüşleri: Eskişehir ili örneği [The opinions of the computer formator teachers on the use of information technology classes: The case of Eskişehir province]. 8th International Educational Technology conference, Mayls 2008, 403-408.

Dursun, Ö. Ö., \& Çuhadar, C. (2009). Bilgisayar öğretmeni adaylarının ögretmenlik mesleğine ilişkin düşünceleri [The opinions of computer teacher candidates about the teaching profession.]. In Proceedings of 9 th International Educational Technology Conference (IETC) bildiri olarak sunulmuştur. 393-399.

Elçi, A. C., \& Sarı, M. (2016). Digital citizenship in the Information Technology and Software course: A scale development study. Journal of Human Sciences, 13(2), 3602-3613. doi:10.14687/jhs.v13i2.3838.

Elçi, A.C., \& Sarı, M. (2016). Bilişim Teknolojileri Ve Yazılım Dersi Öğretim Programına Yönelik Öğrenci Görüşlerinin Dijital Vatandaşlık Bağlamında İncelenmesi [Investigation of Students' Views on Information Technologies and Software Course Curriculum in the Context of Digital Citizenship]. Ç. Ü. Sosyal Bilimler Enstitüsü Dergisi, 25 (3), 87-102.

Erçetin, Ş.Ş., \& Durak, A. (2017). Processing, Problems and Solution Suggestions of Information Technologies and Software Course in Middle Schools: Teacher Opinions. Bartın Üniversitesi Eğitim Fakültesi Dergisi, 6 (1), 159-176.

Erdoğan, M., Kurşun, E., Tan Şişman, G., Saltan, F., Gök, A., \& Yıldız, İ. (2010). A Qualitative Study on Classroom Management and Classroom Discipline Problems, Reasons, and Solutions: A Case of Information Technologies Class. Kuramdan Uygulamaya Ĕgitim Bilimleri, 10 (2), 853 - 891.

Görmez, E. (2016). Öğretmen Adaylarının Dijital Vatandaşlık ve Alt Boyutları Hakkındaki Görüşleri [The Views of Prospective Teachers on Digital Citizenship and SubDimensions]. International Periodical for the Languages, Literature and History of Turkish or Turkic 11 (21), 125-144.

Gürcan, H. İ. (2013). İnternette medya okuryazarlığı yaklaşımı [Media literacy approach on the internet]. https://docplayer.biz.tr/17290489-Internette-medya-okuryazarligiyaklasimi.html Accessed via the internet on 02.02.2019

Karasar, N. (2006). Bilimsel Araştırma Yöntemi [Scientific Research Method]. Ankara: Nobel Yayınc1lik.

Kepenekçi, Y. K. (2008). İnsan Hakları Ve Vatandaşlık. [Human Rights and Citizenship] Ankara: Ekinoks Yayınevi.

Kızılay, N. (2015). Sosyal Bilgiler Öğretmenim: Bana Göre İyi Vatandaş [Social Studies Teacher: Good Citizen,]. Turkish Studies International Periodical for the Languages, Literature and History of Turkish or Turkic, 10 (11), 987-1006. 
Mossberger, K.,Tolbert, C. J., \& McNeal, R. S. (2008). Digital citizenship: The internet, society, and participation. Cambridge: Massachusetts Institute of Technology MIT Press.

Ribble, M. (2011). Digital Citizenship in Schools, (Cilt 2nd Edition). Washington DC: The International Society for Technology in Education (ISTE).

Som Vural, Ş., \& Kurt A. A. (2017). Üniversite Öğrencilerinin Bakış Açısıyla Dijital Vatandaşlık Göstergelerinin İncelenmesi [Investigation of Digital Citizenship Indicators from the Perspective of University Students]. Eğitim Teknolojisi Kuram ve Uygulama, 8(1), 60-80.

Şimşek, E., \& Şimşek, A. (2013). New literacies for Digital citizenship. Contemporary Educational Technology, 4 (2), 126-137.

Board Of Education (2017). Müfredatta Yenileme ve Değişiklik Çalışmalarımız Üzerine [On Renewal and Change in Curriculum]. Ankara, https://ttkb.meb.gov.tr/meb_iys_dosyalar/2017_07/18160003_basin_aciklamasiprogram.pdf Accessed via the internet on 02.02.2019

Board Of Education (2013). Ortaokul yeni ders programı [Secondary school new curriculum]. $\quad$ https://www.memurlar.net/common/news/documents/572077/ek-128052013-22.pdf Accessed via the internet on 05.03. 2019

Board Of Education (2018). Bilişim teknolojileri ve yazılım dersi öğretim programı [Information technology and software course curriculum]. http://mufredat.meb.gov.tr/Dosyalar/2018124103559587-

Bili\%C5\%9Fim\%20Teknolojileri\%20ve\%20Yaz $\%$ C4\%B11\%C4\%B1m\%205-

6.\%20S\%C4\%B1n\%C4\%B1flar.pdf Accessed via the internet on 02.02.2019

Tanrı̈̈̆ğen, A. \& Özel, A. (2011). Bilişim teknolojileri okul formatörü öğretmenlerinin bilişim teknolojisi sınıflarına ilişkin görüşleri (Denizli ili örneği) [Information technologies school formator teachers' opinions on information technology classes (The case of Denizli province).]. e-Journal of New World Sciences Academy, 6 (1), 219-230.

Usta, E., \& Korkmaz, Ö. (2010). Pre-service teachers' computer competencies, perception of technology use and attitudes toward teaching career. Uluslararasi Insan Bilimleri Dergisi, 7(1), 1335-1349. 